Section Editor: IGOR I. KAVASS

\title{
DIRECTOR OF LIBRARY
}

\section{SWISS INSTITUTE OF COMPARATIVE LAW}

The Swiss government is seeking a Director of Library for the recently established Swiss Institute of Comparative Law, located in LausanneDorigny (Vaud). The responsibilities of the Director will include the organization and administration of the library as well as the development of its collection of international and comparative law materials.

Applicants are required to have legal and library education, as well as extensive experience in the administration of law libraries with substantial holdings of comparative and international law materials. They should also be familiar with the structure of the major legal systems and the library application of electronic and other technical equipment. Knowledge of French, German and English languages is essential; knowledge of other languages is desirable. Remuneration will be commensurate to experience (it should be pointed out that it will be internationally competitive).

Applications, including full résumés, lists of publications, references, and other materials, should be sent to Professor Alfred von Overbeck, 14, Fort-St-Jacques, 1700 Fribourg, SWITZERLAND (telephone: 037/24 39 93), the Director of the Institute, from whom further information may be obtained.

\section{LIBRARY COOPERATIVE CUTS COSTS FOR LAW BOOKS}

Over the past few years a promising new option for obtaining American law books at low cost has been developed for the profession. Started in 1978, the Law Library Microform Consortium now offers over 15,000 volumes to its participating libraries at a standard price of $\$ 3.75$ per volume. Over one hundred libraries in the United States and abroad now take advantage of this option for obtaining law books in low-cost, economical-tostore microfiche.

The Consortium is a non-profit operation headquartered in Hawaii. Its board of directors includes librarians from around the United States, and it is further assisted by a National Advisory Board elected by the participating libraries. The National Advisory Board is primarily responsible for the selection of the 5,000 additional volumes of law books which are added to the publications list each year. 